\title{
Child Neurology: Myoclonus-dystonia in Russell-Silver Syndrome
}

\section{Two syndromes caused by one genetic defect}

Joana Martins, MD, Denis Gabriel, MD, Teresa Borges, MD, Gabriela Soares, MD, and Teresa Temudo, MD, PhD Neurology ${ }^{\circledR}$ 2020;95:e936-e938. doi:10.1212/WNL.0000000000010076

A 14-year-old girl presented to our pediatric neurology clinic with complaints of hand jerks noticed since age 6 . The girl reported jerky hand movements that became more severe with time and interfered with daily tasks, particularly eating and writing. Jerks worsened with action and with sudden sound stimulus, were not voluntarily suppressed, and sometimes resulted in accidental item dropping. Responsiveness to alcohol was unknown.

The patient had a history of intrauterine and postnatal growth restriction. She was born small for gestational age (weight $1,850 \mathrm{~g}$, $<5$ th percentile; length $43 \mathrm{~cm}$, $<5$ th percentile; head circumference $32 \mathrm{~cm},<5$ th percentile) and had been treated with growth hormone since age 6 (figure, A). In addition, she presented craniofacial dysmorphic features, such as high forehead, triangular face, gray-bluish sclera and micrognathia (figure, B), mild intellectual disability with learning difficulties, prominent obsessive and depressive symptoms, and attention-deficit/hyperactivity disorder. Low doses of risperidone, methylphenidate, and sertraline had been attempted for small periods of time. Russell-Silver syndrome (RSS) diagnosis was established based on these features, but it was atypical due to the absence of relative macrocephaly at birth and body asymmetry. Genetic analysis of the patient and parents through microsatellite marker testing revealed maternal uniparental disomy of chromosome 7 (mUPD7), confirming the previous diagnosis.

No family history of similar symptoms or other neurologic disorders were identified.

On examination, the patient presented with short stature $(136.2 \mathrm{~cm}$, SD score [SDS] -3.22 , $<5$ th percentile), small head size ( $<5$ th percentile), and prominent forehead and triangularshaped face, all clinically consistent with RSS. Multifocal myoclonus was present at rest and exacerbated when maintaining a posture and during action, with sound stimulus sensitivity (video 1). Myoclonus was more prominent in the head, shoulders, and upper extremities. Segmental dystonia was evident in writing, through writer's cramp, dystonic posture of the forearm, and elevation of the right shoulder. Interposed myoclonic jerks interfered with this task. Slight dystonic postures were evident in the neck with right torticollis and right upper arm during gait. The remaining neurologic examination was normal, as was brain MRI.

The combination of multifocal myoclonus and focal dystonia is consistent with myoclonusdystonia syndrome. A previous erroneous diagnosis of tremor and epilepsy led to prescription of unnecessary medications. This time, clonazepam was prescribed, with partial symptom improvement.

\section{Discussion}

Myoclonus-dystonia is a movement disorder typically characterized by childhood-onset subcortical multifocal myoclonus that predominates over focal/segmental dystonia, with prominent upper body involvement. ${ }^{1}$ The typical phenotype is "lightning-like" myoclonic jerks,

\author{
Correspondence \\ Dr. Martins \\ jcsfmartins@gmail.com
}

MORE ONLINE

- Video

From the Pediatric Neurology Unit (J.M., T.T.) and Pediatric Endocrinology Unit (T.B.), Centro Materno Infantil do Norte; Neurology Department (D.G.); and Medical Genetics Department (G.S.), Centro de Genética Médica Dr. Jacinto Magalhães; Centro Hospitalar Universitário do Porto (J.M., T.B., G.S., T.T.), Porto, Portugal.

Go to Neurology.org/N for full disclosures. Funding information and disclosures deemed relevant by the authors, if any, are provided at the end of the article. 


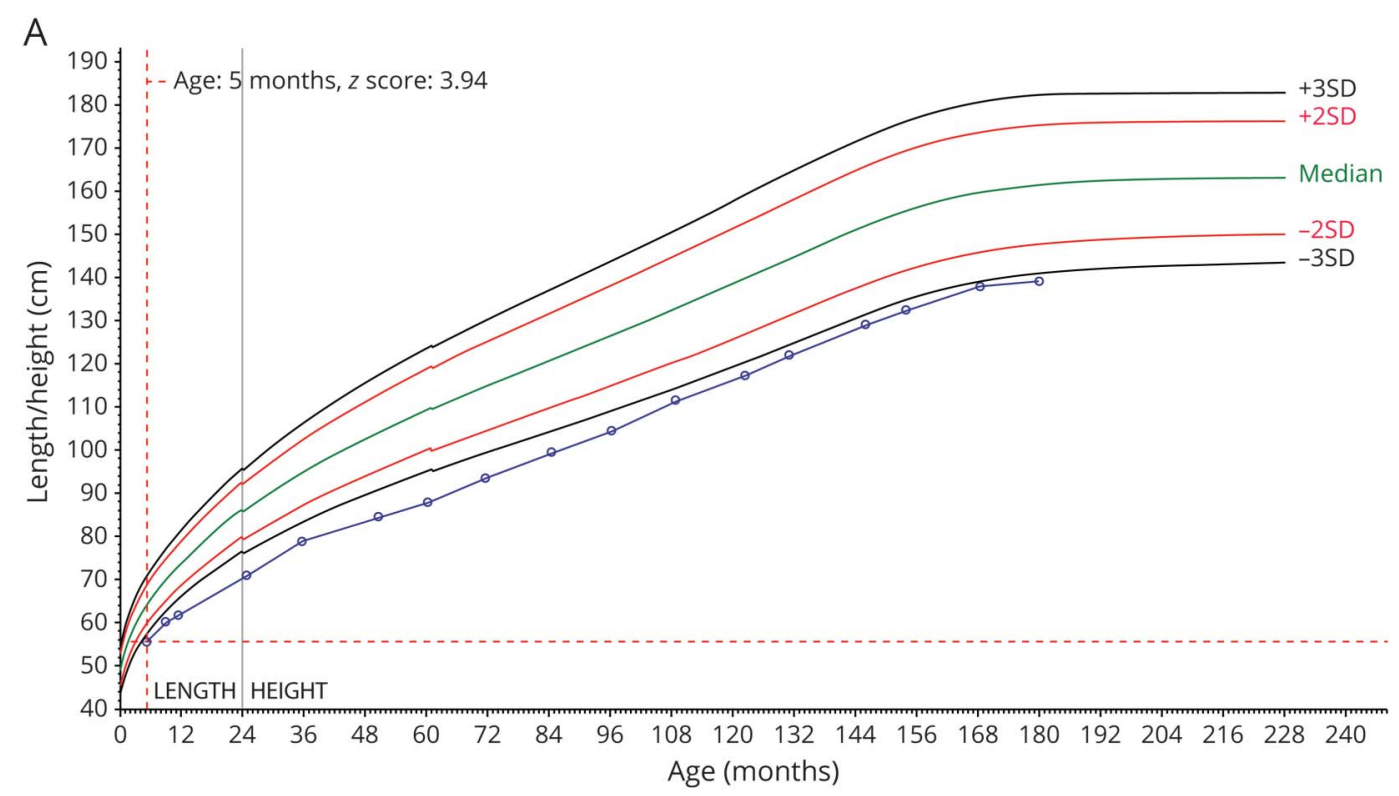

B

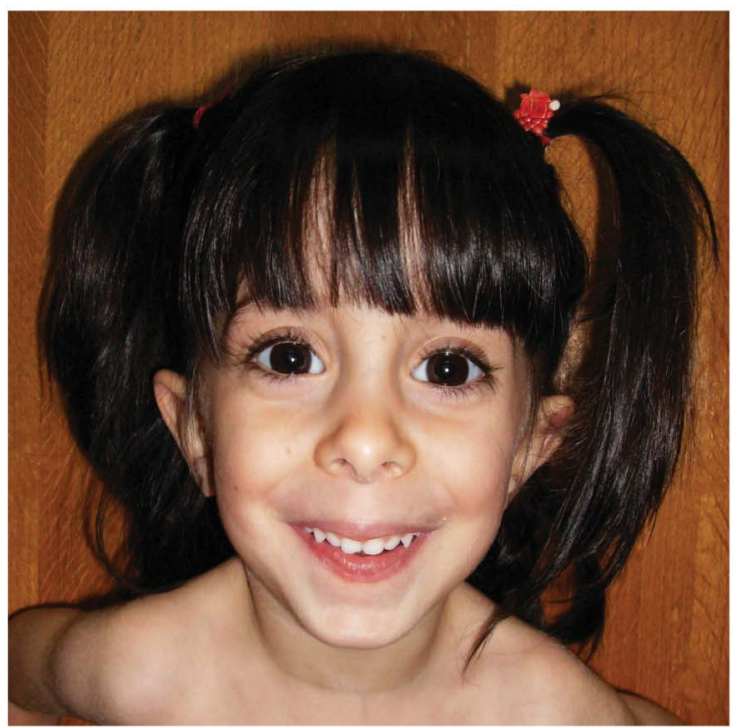

(A) Growth chart demonstrating postnatal growth restriction. (B) Facial appearance of the patient at age 6. Dysmorphic features were evident: high forehead, triangular face, gray-bluish sclera, and micrognathia.

aggravated by action (postural and kinetic myoclonus) and dramatically improved after alcohol ingestion. Myoclonus usually predominates in the proximal segment of the limbs, with less direct involvement of the moving body part (e.g., the hand while writing), although predominantly distal involvement can occasionally be observed. Dystonia is mild to moderate, and usually spares the face, larynx, and trunk. Cervical dystonia and writer's cramp are the most common dystonic manifestations. Isolated dystonia is the initial manifestation in $15 \%-30 \%$ of cases. Additional neurologic features, such as cerebellar ataxia, spasticity, or dementia, are absent. Psychiatric manifestations often accompany motor manifestations and may include anxiety, alcoholism, and obsessivecompulsive disorders.
Myoclonus-dystonia is genetically heterogeneous. Positive family history is common, mainly of dominant paternal transmission. The condition typically results from autosomal dominant loss-of-function mutations in the epsilon-sarcoglycan gene (SGCE; DYT11) on chromosome 7q21. ${ }^{2}$ Other genes and loci have been associated with the disease, including $A D C Y 5, K C T D 17, C A C N A 1 B$, and RELN, and various genes encoding enzymes of the dopaminergic synthesis pathway.

RSS is a rare condition classically defined as the combination of intrauterine and postnatal growth retardation, relative macrocephaly (defined as a head circumference at birth $\geq 1.5$ SDS above birth weight or length SDS), prominent forehead, body asymmetry, and feeding difficulties. ${ }^{3}$ Other typical but 
variable features are triangular face, micrognathia, downturned mouth, crowded or irregular teeth, low-set or posteriorly rotated ears, fifth finger clinodactyly, low muscle mass, excessive sweating, and hypoglycemia. ${ }^{4}$ Motor and speech delay are common. More global developmental delay, mild learning difficulties, and autism spectrum disorder have also been reported.

An underlying genetic defect is identified in $60 \%$ of RSS cases. The most common mechanism is loss of methylation on chromosome 11p15 (11p15 LOM), identified in 30\%-60\% of patients, and mUPD7 in approximately $10 \%$ of cases. ${ }^{5}$ However, abnormalities involving chromosomes 8, 15, 17, and 18 have also been reported. Patients with mUPD7 may have fewer typical or milder RSS clinical features, in addition to motor symptoms, as in the present case. ${ }^{4}$

Unlike most genes that are active from both maternally and paternally inherited chromosomes, imprinted genes are only active from one parental allele. Imprinted genes are therefore regulated according to parent of origin and function in a hemizygous state. Maternally imprinted genes are paternally expressed and maternally silenced. Uniparental disomy results from inheritance of both homologous chromosomes from one parent. The associated phenotype may arise due to either loss of imprinted genes or unmasking of a mutation associated with recessive disease. SGCE gene is maternally imprinted with methylation of the maternal allele, resulting only in expression of the paternal allele and therefore reducing penetrance of maternally transmitted mutations. ${ }^{6}$ In mUPD7, maternal imprinting leads to functional absence of SGCE gene expression, likely to account for the myoclonus-dystonia phenotype. To our knowledge, only 4 reports in the literature describe this association. ${ }^{7-10}$ In one of those, no unmethylated SGCE alleles or transcripts were detected, corroborating this causal mechanism. ${ }^{7}$

Due to the wide spectrum of abnormal physical characteristics and functional abnormalities in RSS, a multidisciplinary approach to these patients is key. Such multidisciplinary teams may include pediatric endocrinologists, pediatric neurologists, clinical geneticists, dieticians, speech therapists, gastroenterologists, and orthopedic surgeons.

Oral symptomatic medications usually have an incomplete and transient effect on myoclonus-dystonia and their use is often limited due to poor tolerability. Anticonvulsive drugs (zonisamide and levetiracetam), benzodiazepines, and anticholinergics should be considered. Although there are no reports of pallidal deep brain stimulation (DBS) in patients with mDUP7, this may be an option in patients with severe forms of myoclonus-dystonia. DBS is effective on both myoclonus and dystonia, with sustained benefit. Botulinum toxin injection for focal dystonic manifestations (particularly efficient in cervical dystonia), physical therapy, and psychotherapy may also be helpful.
Increased awareness of motor symptoms as part of RSS clinical phenotype may raise clinicians' awareness for this underestimated sporadic cause of myoclonus-dystonia. Patients with myoclonus-dystonia unrelated to SGCE mutations and with short stature or characteristic facial features should be tested for mUPD7.

\section{Study funding}

No targeted funding reported.

\section{Disclosure}

The authors report no disclosures relevant to the manuscript. Go to Neurology.org/N for full disclosures.

Appendix Authors

\begin{tabular}{|c|c|c|}
\hline Name & Location & Contribution \\
\hline $\begin{array}{l}\text { Joana } \\
\text { Martins, } \\
\text { MD }\end{array}$ & $\begin{array}{l}\text { Centro Materno Infantil do } \\
\text { Norte, Centro Hospitalar } \\
\text { Universitário do Porto }\end{array}$ & $\begin{array}{l}\text { Study concept and } \\
\text { design, manuscript } \\
\text { drafting, data acquisition, } \\
\text { analysis and } \\
\text { interpretation }\end{array}$ \\
\hline $\begin{array}{l}\text { Denis } \\
\text { Gabriel, } \\
\text { MD }\end{array}$ & $\begin{array}{l}\text { Centro Hospitalar } \\
\text { Universitário do Porto }\end{array}$ & $\begin{array}{l}\text { Data acquisition, analysis } \\
\text { and interpretation }\end{array}$ \\
\hline $\begin{array}{l}\text { Teresa } \\
\text { Borges, } \\
\text { MD }\end{array}$ & $\begin{array}{l}\text { Centro Materno Infantil do } \\
\text { Norte, Centro Hospitalar } \\
\text { Universitário do Porto }\end{array}$ & $\begin{array}{l}\text { Data acquisition, analysis } \\
\text { and interpretation, } \\
\text { manuscript critical } \\
\text { revision }\end{array}$ \\
\hline $\begin{array}{l}\text { Gabriela } \\
\text { Soares, } \\
\text { MD }\end{array}$ & $\begin{array}{l}\text { Centro de Genética Médica } \\
\text { Dr. Jacinto Magalhães, Centro } \\
\text { Hospitalar Universitário do } \\
\text { Porto }\end{array}$ & $\begin{array}{l}\text { Data acquisition, analysis } \\
\text { and interpretation, } \\
\text { manuscript critical } \\
\text { revision }\end{array}$ \\
\hline $\begin{array}{l}\text { Teresa } \\
\text { Temudo, } \\
\text { MD, PhD }\end{array}$ & $\begin{array}{l}\text { Centro Materno Infantil do } \\
\text { Norte, Centro Hospitalar } \\
\text { Universitário do Porto }\end{array}$ & $\begin{array}{l}\text { Study concept and } \\
\text { design, data analysis and } \\
\text { interpretation, } \\
\text { manuscript critical } \\
\text { revision }\end{array}$ \\
\hline
\end{tabular}

\section{References}

1. Roze E, Lang AE, Vidailhet M. Myoclonus-dystonia: classification, phenomenology, pathogenesis, and treatment. Curr Opin Neurol 2018;31:484-490.

2. Zimprich A, Grabowski M, Asmus F, et al. Mutations in the gene encoding $\varepsilon$-sarcoglycan cause myoclonus-dystonia syndrome. Nat Genet 2001;29:66-69.

3. Wakeling EL, Brioude F, Lokulo-Sodipe O, et al. Diagnosis and management of Silver-Russell syndrome: first international consensus statement. Nat Rev Endocrinol 2017;13:105-124.

4. Wakeling EL, Amero SA, Alders M, et al. Epigenotype-phenotype correlations in Silver-Russell syndrome. J Med Genet 2010;47:760-768.

5. Abu-Amero S, Monk D, Frost J, Preece M, Stanier P, Moore GE. The genetic aetiology of Silver-Russell syndrome. J Med Genet 2008;45:193-239.

6. Grabowski M, Zimprich A, Lorenz-Depiereux B, et al. The epsilon-sarcoglycan gene (SGCE), mutated in myoclonus-dystonia syndrome, is maternally imprinted. Eur J Hum Genet 2003;11:138-144.

7. Guettard É, Portnoi M-F, Lohmann-Hedrich K, et al. Myoclonus-dystonia due to maternal uniparental disomy. Arch Neurol 2008;65:1380-1385.

8. Augustine EF, Blackburn J, Pellegrino JE, Miller R, Mink JW. Myoclonus-dystonia syndrome associated with Russell Silver syndrome: letters: new observation. Mov Disord 2013;28:841-912.

9. Sheridan M, Bytyci Telegrafi A, Stinnett V, et al. Myoclonus-dystonia and SilverRussell syndrome resulting from maternal uniparental disomy of chromosome 7 : myoclonus-dystonia and Silver-Russell syndrome. Clin Genet 2013;84:368-372.

10. Stark Z, Ryan MM, Bruno DL, Burgess T, Savarirayan R. Atypical Silver-Russell phenotype resulting from maternal uniparental disomy of chromosome 7. Am J Med Genet A 2010;152A:2342-2345. 


\section{Neurology}

\section{Child Neurology: Myoclonus-dystonia in Russell-Silver Syndrome: Two syndromes caused by one genetic defect}

Joana Martins, Denis Gabriel, Teresa Borges, et al.

Neurology 2020;95;e936-e938 Published Online before print July 7, 2020

DOI 10.1212/WNL.0000000000010076

\section{This information is current as of July 7, 2020}

\section{Updated Information \&} Services

References

Subspecialty Collections

Permissions \& Licensing

Reprints including high resolution figures, can be found at: http://n.neurology.org/content/95/7/e936.full

This article cites 10 articles, 2 of which you can access for free at: http://n.neurology.org/content/95/7/e936.full\#ref-list-1

This article, along with others on similar topics, appears in the following collection(s):

All Pediatric

http://n.neurology.org/cgi/collection/all_pediatric

Dystonia

http://n.neurology.org/cgi/collection/dystonia

Myoclonus

http://n.neurology.org/cgi/collection/myoclonus

Information about reproducing this article in parts (figures,tables) or in its entirety can be found online at:

http://www.neurology.org/about/about_the_journal\#permissions

Information about ordering reprints can be found online:

http://n.neurology.org/subscribers/advertise

Neurology ${ }^{\circledR}$ is the official journal of the American Academy of Neurology. Published continuously since 1951, it is now a weekly with 48 issues per year. Copyright () 2020 American Academy of Neurology. All rights reserved. Print ISSN: 0028-3878. Online ISSN: 1526-632X.

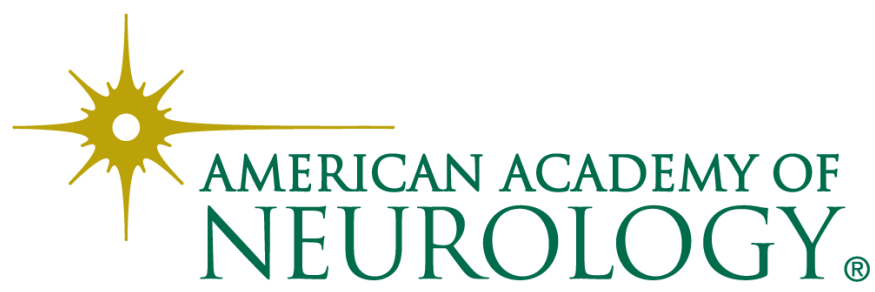

